\title{
Snap Bean Variety Trials in East-Central Puerto Rico
}

\author{
Oscar D. Ramírez and J. Vélez-Santiago ${ }^{1}$
}

\section{INTRODUCTION}

Snap beans are one of the most valuable crops grown by home and market gardeners and by truck farmers for shipment and canning.

The use of improved varieties may contribute to raising the production and, at the same time, consumption can be stimulated because of the better quality of the new varieties tested. Before recommending new varieties these should be properly tested to evaluate their quality and adaptability to the area. So trials of commercial varicties and breeding lines are conducted under various soil and climatic conditions.

This paper reports the results of two such trials.

\section{POLE BEANS}

\section{MATERIALS AND METHODS}

Five varicties $(1)^{2}$ of pole beans, namely Florigreen, Kentucky 191, Blue Lake 92, Blue Lake 228, and Blue Lake 231, were tested at the Gurabo Substation farm in east-central Puerto Rico, following a $5 \times 5$ latin-square design. Each plot consisted of two rows 20 feet long and 4 feet apart with 10 hills 2 feet apart per row and 2 plants per hill. A 9-10-5 fertilizer was applied at the rate of 800 pounds per acre (2) at planting time. The beans were planted on November 25, 1959.

The varicties tested are commercially grown in the United States and are considered high yielders of excellent quality, with good processing appearance and flavor.

The pods were harvested at the best edible stage. All varieties were harvested 12 times except Blue Lake 92 with only 10 pickings.

\section{EXPERIMENTAL RESULTS AND DISCUSSION}

The results obtained in the pole-bean variety trial are presented in tables 1 and 2.

Florigreen ( $(3)$ outyielded Kentucky 191 significantly at the 1-percent level. There were no significant differences in yield between varieties Florigreen, Blue Lake 228, Blue Lake 92, and Blue Lake 231. Florigreen with a production of 4.30 tons of green beans per acre ranked first among the pole

1 Assistant Plant Breeder and Research Assistant in Horticulture, respectively, Agricultural Experiment Station, University of Puerto Rico, Río Piedras and Gurabo, P.R.

2 Italic numbers in parentheses refer to Literature Cited, pp. 217-8. 
beans tested. This production was much higher than that obtained at the Lajas Substation, which was 2.74 tons per acre (4). Beside being the highest in yield Florigreen was highly resistant to bean rust and mosaic, two of the worst diseases of beans. Judging from the results of this trial, this variety seems to be very well adapted to east-central Puerto Rico.

TABLE 1.-Harvesting dates and maturity at harvest of 5 pole-bean varieties, blooming on Dec. 28, 1959 at the Gurabo Substation, planted Nov. 25, 1959

\begin{tabular}{|c|c|c|}
\hline Variety & Harvesting dates & $\begin{array}{l}\text { Days of maturity at } \\
\text { first harvest }\end{array}$ \\
\hline Florigreen & $\begin{array}{l}\text { Jan. } 14,15,18,21,22,25,28 \\
\text { Feb. } 1,4,8,12,15\end{array}$ & 50 \\
\hline Blue Lake 228 & $\begin{array}{l}\text { Jan. } 18,21,22,25,28 \\
\text { Feb. } 1,4,8,12,15\end{array}$ & 54 \\
\hline Blue Lake 92 & $\begin{array}{l}\text { Jan. } 14,15,18,21,22,25,28 \\
\text { Feb. } 1,4,8,12,15\end{array}$ & 50 \\
\hline Blue Lake 231 & $\begin{array}{l}\text { Jan. } 14,15,18,21,22,25,28 \\
\text { Feb. } 1,4,8,12,15\end{array}$ & 50 \\
\hline Kentucky 231 & $\begin{array}{l}\text { Jan. } 14,15,18,21,22,25,28 \\
\text { Feb. } 1,4,8,12,15\end{array}$ & 50 \\
\hline
\end{tabular}

TABLE 2.-Total and mean yields of 5 pole-bean varieties at the Gurabo Substation, planted Nov. 25,1959

\begin{tabular}{l|c|c|c}
\hline \multicolumn{1}{c|}{ Variety } & Total yield & Mean yield per plot & $\begin{array}{c}\text { Calculated produtcion } \\
\text { per acre }\end{array}$ \\
\cline { 2 - 3 } Florigreen & $L b$. & $L b$. & $T . / A$. \\
Blue Lake 228 & 157.91 & 31.58 & 4.30 \\
Blue Lake 92 & 113.95 & 26.79 & 3.65 \\
Blue Lake 231 & 125.20 & 25.04 & 3.41 \\
Kentucky 191 & 95.27 & 19.05 & 2.59 \\
& 91.58 & 18.31 & 2.49 \\
\hline
\end{tabular}

As in the Lajas trial, variety Kentucky 191 yielded less at Gurabo too. Moreover, it was severely attacked by bean mosaic, which susceptibility makes it undesirable for commercial production in Puerto Rico.

The standard error and least differences required for significance between mean yields in table 2 are shown in the following tabulation: 
Itemt

Difference between highest and lowest

Difference between highest and 2nd lowest

Difference between highest and 3d lowest

Difference between highest and 4th lowest

Standard error 1.75 with 4 d.f.

$\begin{array}{cr}5 \text { percent } & 1 \text { percent } \\ 7.89 & 10.22 \\ 7.35 & 9.62 \\ 6.59 & 8.82 \\ 5.39 & 7.56\end{array}$

\section{BUSH BEANS}

\section{MATERIALS AND METHODS}

On February 9, 1961 an experiment using eight breeding lines received from the Southeastern Vegetable Breeding Laboratory at Charleston, S.C., and two commercial varieties of bush snapbeans was planted at the Gurabo Substation farm. The breeding lines (5) planted were: B2971-1-1, B3370, B3095-3, B3489, B3125 x 5-2, B2567-1, B3365, and B3076. The commercial varieties tested were Wade (1) and Top Crop (1).

The experimental design used was a randomized block with 4 replicates. Each plot consisted of 2 rows 20 feet long and 3 feet apart with 40 plants per row spaced 6 inches apart, equivalent to 80 plants per plot. A 9-10-5) fertilizer was applied at the planting time, at the rate of 800 pounds per acre.

The pods were picked at their best edible stage until the harvesting of the crop was completed. Pickings were made at intervals of 3 to 5 days, more or less. All varieties were harvested six times except B2971-1-1, B3095-3, and B3076 with only five pickings.

\section{EXPERIMENTAL RESULTS AND DISCUSSION}

The results obtained in this bush snap bean variety trial are shown in tables 3 and 4.

Line B2971-1-1 outyielded Wade and B3076 significantly at the 1-percent level. There were no significant differences between the rest of the breeding lines and varieties tested. The production of line B2971-1-1, 4.05 tons of green beans per acre, is very high for a bush bean here in Puerto Rico. This line outyielded two very important commercial varieties, Top Crop and Wade, which ranked first and second in an experiment at the Lajas Substation, with a production of 3.86 and 3.34 tons (4) of green beans per acre, respectively. Line 2971-1-1 also showed some degree of resistance to bean mosaic and rust, and its pod appearance and quality were very good.

The standard error and least differences required for significance between means yields in table 4 are shown in the following tabulation: 
TABLE 3.-Harvesting dates and maturity at harvest of 10 bush snap bean varieties and breeding lines at the Gurabo Substation, planted Feb. 9, 1961

\begin{tabular}{|c|c|c|c|}
\hline Variety & $\begin{array}{c}\text { Blooming dates } \\
(1961)\end{array}$ & Harvesting dates & $\begin{array}{c}\text { Days of } \\
\text { maturity at first } \\
\text { harvest }\end{array}$ \\
\hline B2971-1-1 & Mar. 13 & $\begin{array}{l}\text { Mar. } 28 \\
\text { Apr. } 4,7,12,18\end{array}$ & 47 \\
\hline B3370 & Mar. 10 & $\begin{array}{l}\text { Mar. } 25,28 \\
\text { Apr. } 4,7,12,18\end{array}$ & 44 \\
\hline B3095-3 & Mar. 13 & $\begin{array}{l}\text { Mar. } 28 \\
\text { Apr. } 4,7,12,18\end{array}$ & 47 \\
\hline B3489 & Mar. 10 & $\begin{array}{l}\text { Mar. } 25,28 \\
\text { Apr. } 4,7,12,18\end{array}$ & 44 \\
\hline B3125 $\times 5-2$ & Mar. 10 & $\begin{array}{l}\text { Mar. } 25,28 \\
\text { Apr. } 4,7,12,18\end{array}$ & 44 \\
\hline B2567-1 & Mar. 10 & $\begin{array}{l}\text { Mar. } 25,28 \\
\text { Apr. } 4,7,12,18\end{array}$ & 44 \\
\hline Top Crop & Mar. 10 & $\begin{array}{l}\text { Mar. } 25,28 \\
\text { Apr. } 4,7,12,18\end{array}$ & 44 \\
\hline B3365 & Mar. 10 & $\begin{array}{l}\text { Mar. 25, } 28 \\
\text { Apr. } 4,7,12,18\end{array}$ & 44 \\
\hline Wade & Mar. 10 & $\begin{array}{l}\text { Mar. 25, } 28 \\
\text { Apr. } 4,7,12,18\end{array}$ & 44 \\
\hline $\mathrm{B} 3076$ & Mar. 13 & $\begin{array}{l}\text { Mar. } 28 \\
\text { Apr. } 4,7,12,18\end{array}$ & 47 \\
\hline
\end{tabular}

TABLE 4.-Tolal and mean yields of 10 snap bean varieties and breeding lines at the Gurabo Substation, planted Feb. 9, 1961

\begin{tabular}{l|c|c|c}
\hline \multicolumn{1}{c|}{ Variety } & Total yield & Mean yield per plot & Calculated production \\
\cline { 2 - 3 } B2971-1-1 & $0 z$. & 0. & $T . / A$. \\
B3370 & 1,431 & 357.75 & 4.058 \\
B3095-3 & 1,155 & 288.75 & 3.275 \\
B3489 & 1,076 & 269.00 & 3.051 \\
B3125 X 5-2 & 968 & 242.00 & 2.745 \\
B2567-1 & 966 & 241.50 & 2.739 \\
Top Crop & 934 & 233.50 & 2.648 \\
B3365 & 880 & 220.00 & 2.495 \\
Wade & 872 & 218.00 & 2.472 \\
B3076 & 691 & 172.75 & 1.959 \\
& 686 & 171.50 & 1.945 \\
\hline
\end{tabular}




\begin{tabular}{lrr}
\multicolumn{1}{c}{ Ilem } & 5 percent & I percent \\
Difference between highest and lowest & 117.89 & 141.16 \\
Difference between highest and 2nd lowest & 115.26 & 138.50 \\
Difference between highest and 3d lowest & 112.21 & 135.59 \\
Difference between highest and 4th lowest & 108.82 & 132.23 \\
Difference between highest and 5th lowest & 104.84 & 128.25 \\
Difference between highest and 6th lowest & 100.13 & 123.54 \\
Difference between highest and 7th lowest & 93.60 & 117.37 \\
Difference between highest and 8th lowest & 84.78 & 108.69 \\
Difference between highest and 9th lowest & 72.21 & 94.92
\end{tabular}

\section{SUMMARY}

Two snap bean variety trials were planted at the Gurabo Substation farm in east-central Puerto Rico. In the first trial five pole-bean varieties were tested. The varieties used were: Florigreen, Blue Lake 92, Blue Lake 228, Blue Lake 231, and Kentucky 191. Of these varieties Florigreen had the highest yield with a production of 4.30 tons of green beans per acre. It also showed high resistance to bean rust and mosaic, two of the worst diseases of beans.

In the second trial eight lines and two commercial bush varieties were tested. They are B2971-1-1, B3370, B3095-3, B3489, B3365, B3125 x 5-2, B2567-1, B3076, Wade, and Top Crop. In this trial line B2971-1-1 produced the best yield with a production of 4.05 tons of green beans per acre, which is very high for bush beans in Puerto Rico.

\section{RESUMEN}

En la Subestación de Gurabo se llevaron a cabo dos experimentos comparativos con habichuelas tiernas.

En uno de los experimentos se sembraron cinco variedades trepadoras, a saber: Florigreen, Blue Lake 92, Blue Lake 228, Blue Lake 231 y Kentucky 191. Entre éstas, la Florigreen fue superior tanto por su alto producción (4.30 T./A.), como por su alta resistencia al mosaico y a la roya de la habichuela.

En otro experimento se probaron 10 líneas y variedades de habichuelas ticrnas arbustivas. Estas fueron B2971-1-1, B3370, B3095-3, B3489, B3125 $\times$ 5-2, B2567-1, B3365, B3076, Wade y Top Crop. La línea B2971-1-1 fue superior, pues produjo 4.05 toneladas de habichuelas tiernas por cuerda, lo que se considera es una producción sobre lo normal para Puerto Rico.

\section{LITERATURE CITED}

1. A Descriptive Catalog of Vegetables, No. 19, Asgrow Export Corp., Milford, Conn.

2. Compendio de Recomendaciones para la Producción de Cosechas, Pub. Misc. 1, Est. Exp. Agr. Univ. P.R., (rev.) 1954. 
3. Walter, J. M., and Lorz, A. P., Florigreen, A Disease-Resistant Pole Bean, Circ. S-92, Fla. Agr. Exp. Sta., 1956.

4. Ramfrez, O. D., and Quiñones, J. A., Snap bean variety trials at the Lajas Substation, J. Agr. Univ. P.R., 46 (1) 26-31, 1961.

5. Nineteenth, Twentieth, and Twenty-first Annual Report of Vegetable Breeding in the Southeastern United States, Hawaii, and Puerto Rico, Southeastern Vegetable Breeding Laboratory, Agricultural Research Service, USDA, Charleston, S. C., 1958, 1959, 1960. 